\title{
Australian local government's contribution to good governance on major projects: increasing information, participation and deliberation
}

\section{Commonwealth Journal of Local Governance \\ Issue 24: June 2021}

http://epress.lib.uts.edu.au/ojs/index.php/cjlg

\author{
Sarah de Vries \\ School of Earth and Environmental Sciences and \\ Centre for Policy Futures \\ University of Queensland \\ Brisbane \\ Australia
}

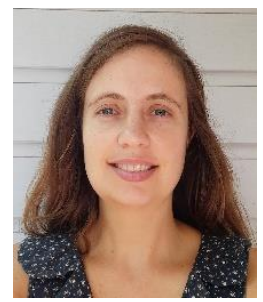

Email: Sarah.devries@uq.edu.au

\begin{abstract}
Decision-making for major projects is often outside the legal remit of local governments in Australia. Nevertheless, local governments are the legitimate representatives of their communities and as such, can potentially make an important contribution to the decision-making process. However, little is known about how they may do so. This paper addresses that gap by analysing two case studies: Coal Seam Gas projects in northern New South Wales and the proposed East West Link tunnel in Melbourne. The research finds that local governments can contribute to good governance by increasing the quality and availability of information, community participation, and opportunities for local deliberation. However, this study also found a number of barriers to local governments making these contributions, which can disincentivise and limit local advocacy. The paper suggests there may be a range of benefits to be gained by reducing those barriers.
\end{abstract}

Keywords: Local government, good governance, major projects, advocacy, community engagement

\section{Introduction}

It is generally agreed that governments strive towards good governance in their decision-making practices. Governance is about how decisions are made - who is included and who is excluded from the process - and therefore has a strong influence over the distribution of power in decision-making systems (Graham et al. 2003). The academic literature proposes a number of principles of good governance. Pomeranz and Stedman's (2020) recent review of this literature identifies eight: inclusivity, fairness, performance, transparency, legitimacy, accountability, direction and capability. These were used to inform the research reported here, but since each captures a vast body of work, a detailed review is beyond the scope of this paper.

DOI: https://doi.org/10.5130/cjlg.vi24.7637

Article History: Received 01/07/20; Accepted 10/12/20; Published 28/06/21

Citation: Commonwealth Journal of Local Governance 2021, 24: 60-78, https://doi.org/10.5130/cjlg.vi24.7637

(c) 2020 Sarah de Vries. This is an Open Access article distributed under the terms of the Creative Commons Attribution 4.0 Unported (CC BY 4.0) License (https://creativecommons.org/licenses/by/4.0/), allowing third parties to copy and redistribute the material in any medium or format and to remix, transform, and build upon the material for any purpose, even commercially, provided the original work is properly cited and states its license. 
Local governments play a key role in the drive towards good governance. In Australia, they are a creation of state governments, with limited formal powers and sources of funding, and subject to a high degree of oversight by higher levels of government (Coghill et al. 2014; Grant and Dollery 2012). Similar situations exist in other countries. As a result, there is literature and practical guidance directed towards promoting good governance by local governments (Amosa 2010; Lawton and Macaulay 2014; Muyomba-Tamale and Cunningham 2019; VLGA et al. 2012). However, less attention has been paid to the contribution that local governments make to the quality of governance in situations where decision-making rests with another level of government. And while advocacy is something local governments commonly engage in, it is not a process which is well understood (Henderson 2017). Also worthy of note is that a number of disincentives exist in Australia to local governments opposing state government positions, since the state governments have legal powers over local government boundaries, electoral practices, funding and responsibilities; and can also place local governments under administration in certain circumstances (Henderson 2018).

Nevertheless, there is theoretical support for the notion that local government advocacy can contribute to good governance. Some proponents advocate for greater local government autonomy (Ladner et al. 2019; Van Assche and Dierick 2007); while others support increasing the decentralisation of decisionmaking to improve the quality of governance, including the level of citizen engagement (Hendriks et al. 2013; Katz and Nowak 2017; Schoburgh and Ryan 2017; Stoker 2006). However, there will always be limits to decentralisation and to local autonomy, with good governance requiring a balance of topdown and bottom-up dynamics to ensure equity and coordination as well as solutions that are locally appropriate and self-determined (Dovers and Hussey 2013; Heywood 2011; Thwaites et al. 2004). Pratchett (2004) further suggests that local governments' ability to influence decisions made at higher levels of government is an essential aspect of autonomy. Therefore, the argument runs, good governance will include a role for local governments in representing the views of their communities on policy areas outside their legal jurisdiction: for example large development projects which, although they are not always suited to decentralised decision-making, nevertheless have significant local impacts, often crossing multiple local government areas and exhibiting ramifications well beyond their footprint.

In addition, the proliferation of interest in deliberative democracy has increased the prominence of local governments in contributing to the quality of decision-making on broader societal issues. Deliberative democracy emphasises the importance of dialogue, reason-giving and reflection prior to decisionmaking (Gutmann and Thompson 2000; Smith 2016). However, effective dialogue often requires a restricted number of participants, and the top-down institutions of central governments have limitations in their ability to provide such opportunities (Dryzek 2010). By contrast, local governments around the world have been at the forefront of experimenting with ways to create inclusive and deliberative spaces (Ercan and Hendriks 2013). 
The literature on deliberative democracy continues to evolve, with a growing focus on systems which "acknowledge that no single forum, however ideally constituted, could be sufficient to legitimate the collective decisions that democracies adopt" (Mansbridge et al. 2012, p. 1). This pluralistic approach creates new opportunities for analysing political systems in light of deliberative theory, but also highlights the need to resolve the way that the deliberative and representative dynamics of decisionmaking systems interact (Schafer 2017). As the level of government closest to people, local governments operate at this intersection, helping decision-making systems become more participatory and deliberative (Coghill et al. 2014; Crowley 1998).

In Australia, decision-making for major projects typically rests with state governments, with the federal government able to intervene under circumstances of national interest. Local governments may be treated no differently from any other stakeholder, even though a number of potential benefits and opportunities have been identified from involving them more closely in major project decision-making (KPMG 2015). This paper investigates the question: 'how do local governments contribute to good governance for major project decision-making?' In doing so, it considers how local governments contribute to good governance for major projects; identifies barriers to local governments fulfilling this role; and explores the implications of these findings for the future role of local governments.

\section{Research methods}

The research used a case study approach based on 'least similar case comparison', where more than one case study of a completed project or activity is selected for analysis, and where the outcomes have been the same, but different antecedent conditions obtained. The aim of this approach is to explore as many causes as possible that could lead to the same end (Bennett 2004). Data was collected via in-depth interviews and document analysis. Documents analysed included local government council minutes and reports, media articles, state government media statements and policy documents, plans and legislation, legal proceedings, and information provided by some interview participants. Interviewees were selected for their proximity to, and knowledge of, local government activities relating to the major projects being analysed. They included respondents from local government (11), the community (10), state government (2) and the legal sector (one), resulting in a total of 24 in-depth interviews. ${ }^{1}$ The variety of data sources enabled triangulation of evidence to improve confidence as to the accuracy of research findings. The analysis process drew on techniques including discourse analysis, process tracing and grounded theory.

\footnotetext{
${ }^{1}$ Data from the interviews are referred to in this paper using a coding system which includes the sector of the interviewee and the number of the interview, for example the second local government councillor to be interviewed is referred to as 'Local Government 2'.
} 


\section{Conceptual framework}

A number of principles of good governance are cited across the literature (Graham et al. 2003; Lockwood et al. 2010; UNDP 2006). However, as noted above Pomeranz and Stedman's recent literature review synthesises these into eight principles: transparency, performance, accountability, inclusivity, fairness, legitimacy, direction and capability (Pomeranz and Stedman 2020). The conceptual framework for this research analyses those principles against the types of advocacy undertaken by local governments as listed below. There is a significant degree of inter-relatedness between the principles. This is evidenced by the way they are variously described and classified across the literature, as well as by Pomeranz and Stedman's (2020) finding that demarcation lines defined in the literature are not necessarily borne out in practice. For these reasons, this analysis is organised by addressing in turn each of the two types of advocacy actions that local governments undertook, with the related primary good governance principles discussed under each (see Box 1). The paper then goes on to discuss the barriers that local governments face in making these contributions, which informs a discussion on the future role of local governments in contributing to good governance for major projects.

\section{Box 1: Types of advocacy and related good governance principles Information provision and policy rationale}

- Transparency: rationale for decision-making is clearly communicated; information is freely available and accessible.

- Performance: effectiveness and efficiency; processes meet their objectives while making best use of resources.

- Accountability: governing body takes responsibility and is answerable for its decisions; demonstrates fulfilment of responsibilities.

- Capability: Resources, skills, leadership, knowledge of governing body.

\section{Increasing participation and deliberation}

- Inclusivity: all stakeholders have opportunities to participate in and affect decision-making.

- Fairness: governing body and its decision-making process respects diverse stakeholder views, without bias; considers costs/benefit distribution.

- Legitimacy: governing body has authority to make decisions by rule of law or via stakeholders; authority used with integrity.

- Direction: Strategic vision; looking constructively towards the future.

(Definitions from Pomeranz and Stedman 2020, p. 430)

\section{Outline of case studies}

This research analyses two cases where local governments were highly engaged in advocacy on behalf of their communities: the East West Link tunnel project in Melbourne, Victoria; and Coal Seam Gas projects in northern New South Wales (NSW). Both are exceptional examples of major turnarounds in public policy positions by state governments in Australia in relation to major projects. In both cases, pressure from local communities and local governments was significant in influencing the policy 
change. Victoria and NSW have differing structures for local government community engagement. In NSW, the Local Government Act lists community participation as one of the principles of local government and mandates the development of a community engagement strategy to inform community strategic plans (Local Government Act 1993 (NSW)). In Victoria, the Local Government Act that was in effect at the time of this case study went further, as its preamble drew attention to the standing of local government as a 'distinct and essential tier of government' in the Victorian Constitution and included in the role of local government "to provide governance and leadership for the local community through advocacy, decision-making and action" (Local Government Act 1989 (Victoria)). This statement suggests a broad remit for local governments and provides strong support for the view that they should not just engage with their communities, but also advocate for their wishes. In 2020, however, the Victorian Local Government Act was updated to include more emphasis on deliberative engagement, but no longer including reference to advocacy.

The actions taken by local governments in the case studies are compared with the legislative requirements in their jurisdictions in the discussion section of this paper, including reflection on the direction of the revised Victorian Local Government Act 2020.

\section{East West Link, Melbourne 2012-2014}

The East West Link, a tunnel project to link two major Melbourne freeways, was announced in 2012, by the then Liberal-controlled Victorian state government. The tunnel would have had direct impacts on the inner Melbourne suburbs of Fitzroy, Collingwood and North Melbourne, among others, as well as important public places such as Melbourne Zoo and Royal Park. The East West Link had been first proposed in a major transport policy document in 2008 and was seen as the project to join "the last of the unconnected freeways leading towards the city" (Eddington 2008, p. 129). Key reasons for opposition to the project included the social, environmental and health impacts of roads and car travel, as well as loss of local amenity. In addition, there were procedural concerns, and the cost-benefit analysis of the project was not made public. A number of groups opposed the project, including the communities impacted, public transport groups, environment groups and local governments. Yarra City Council started its own weekly protest near the proposed site to promote its alternative vision of 'Trains not toll roads' to passing traffic. Yarra and Moreland City Council mayors are seen holding this signage below in Figure 1.

Yarra City Council and Moreland City Council jointly lodged a legal action calling into question the validity of the project's approval and demanding transparency over the cost-benefit analysis. In response, the Labor opposition sought legal advice which it cited when it changed its policy stance on the project, from one of honouring contracts if signed to a position of walking away from signed contracts due to legal uncertainty around their validity. 
Figure 1: Yarra City Council and Moreland City Council mayors holding 'Trains not toll roads' placards at anti-freeway protests

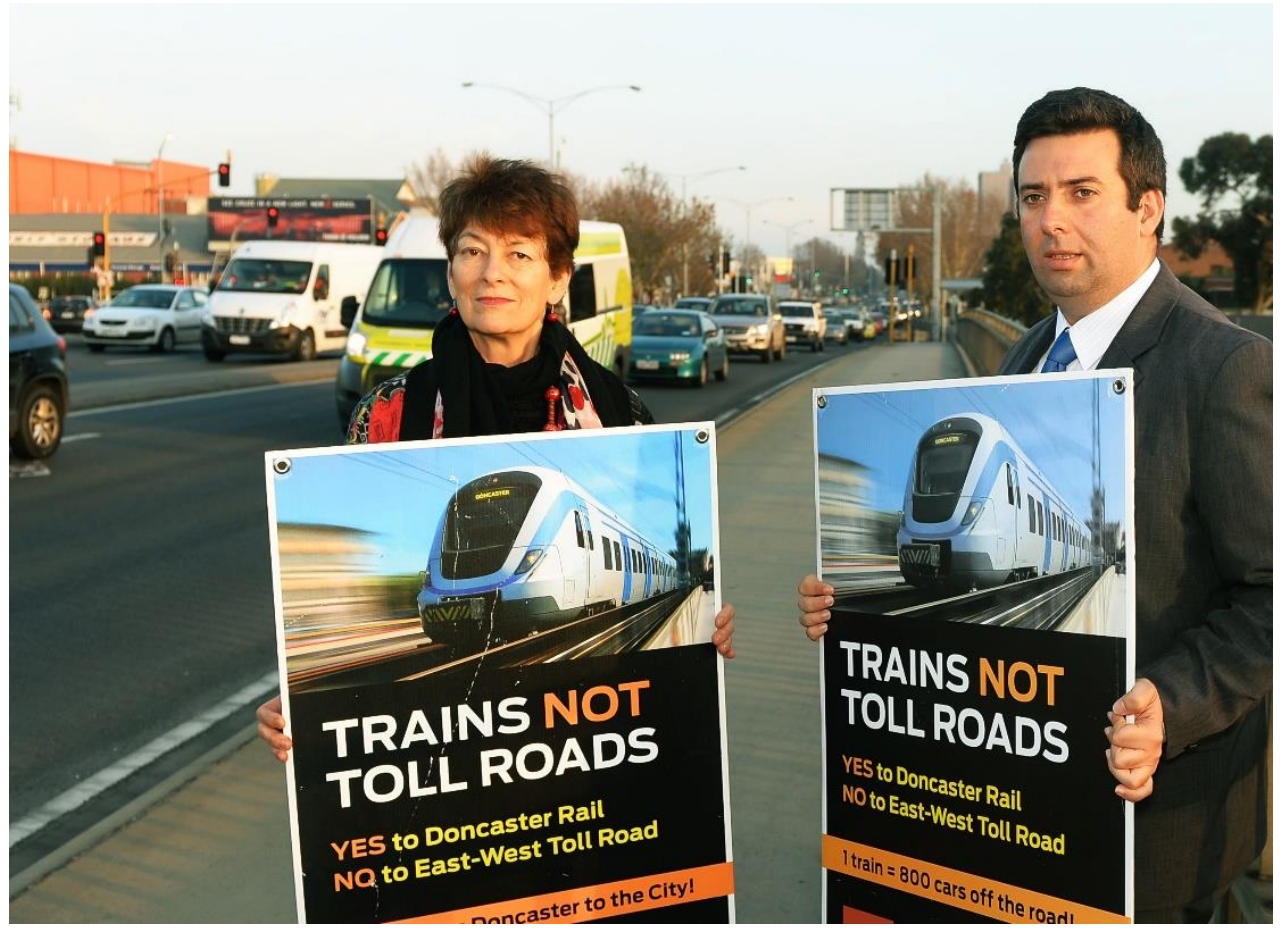

Source: Ainsworth (2014). Photographer: Carmelo Bazzano, Newscorp Australia

In spite of this high level of opposition to the project and with a state government election just weeks away, the incumbent government proceeded to sign contracts for the project. At the election, there was a change of government, and the new Labor Government followed through on its commitment to abandon the project, despite it costing approximately AUD339 million to do so (Lucas and Gordon 2015).

\section{Coal Seam Gas, Northern Rivers region, NSW 2010-2015}

Prior to 2010, a number of coal seam gas (CSG) licences had been approved in Northern NSW. CSG is extracted by an unconventional method which drills into coal seams, changing the pressure in order to extract gas (Maloney 2015). The industry has attracted controversy and opposition in a number of jurisdictions where it has been proposed, with varying reactions by governments (McGowan 2012; Williams 2020). As test drilling and associated pipeline development commenced in Northern NSW in 2010, community opposition started to grow. The community self-surveyed door-to-door, and hundreds of streets across a number of communities signed 'road declarations' to declare themselves 'CSG-free' - an approach that spread to other regions. Figure 2 below shows the Lismore City mayor with a campaign organiser, Annie Kia, holding baskets of 'CSG-free' declarations. 
Figure 2: Lismore mayor Jenny Dowell and Annie Kia holding baskets full of 'CSG-free' community declarations

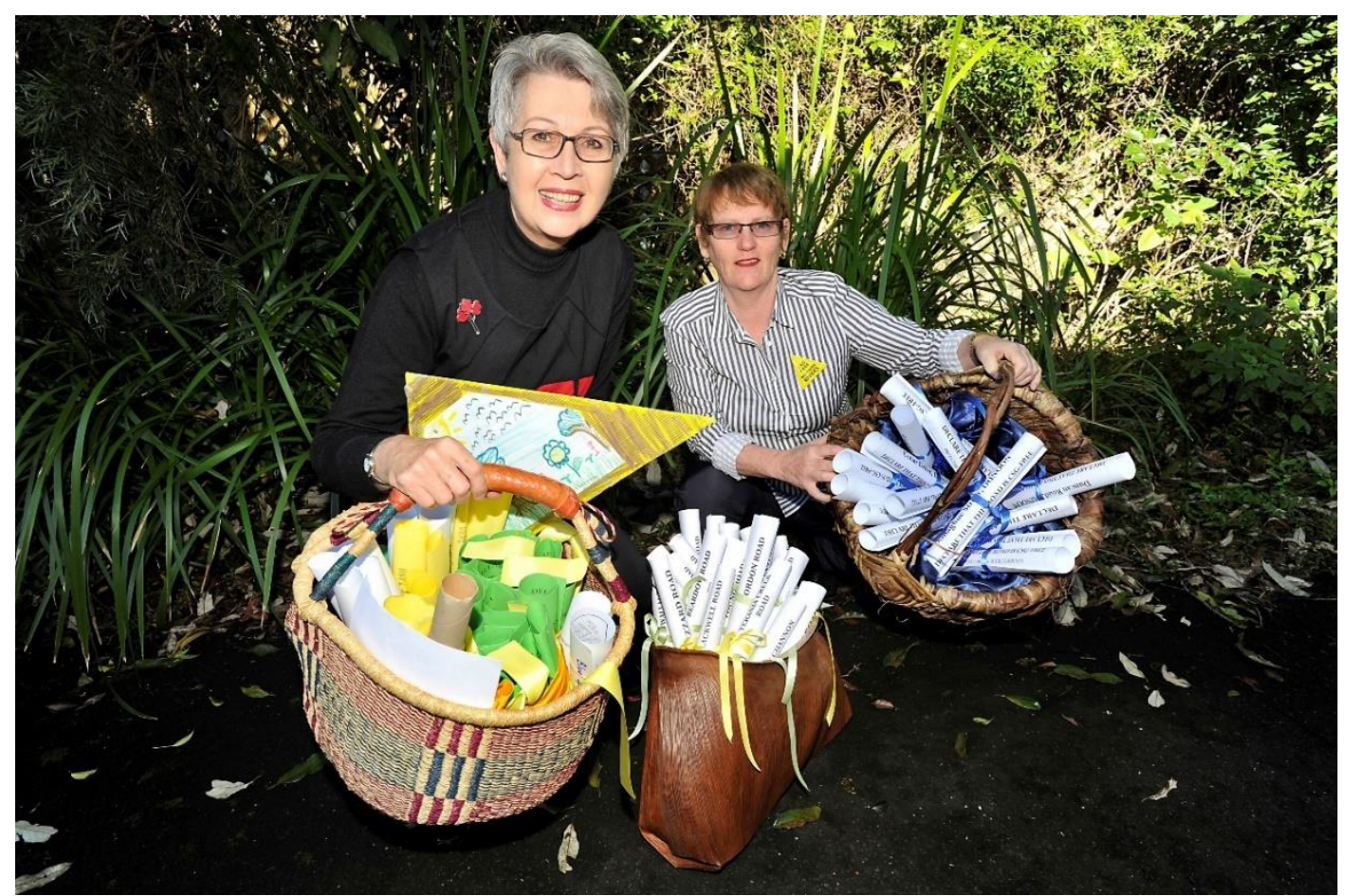

Source: Mireille Merlet-Shaw, Newscorp Australia ('Lismore residents CSG vote’ 2012)

A number of local governments in addition to Lismore were against the development of CSG in the region, including Byron, Tweed and, after the 2012 election, Kyogle. Lismore City Council was public about its opposition to CSG as early as 2010 (Lismore City Council 2018), and had the potential to be significantly impacted by CSG. The City ran a poll at its election in 2012, finding $87 \%$ of people in the municipality opposed to CSG. Key organisations came out publicly against CSG, including the NSW Farmers' Federation and NORCO, the largest dairy cooperative in Australia. Pressure mounted on the NSW state government to change its position: actions included protests, letters to government, meetings with ministers and advisers, and demonstrators blocking work at drilling operations. As the state government continued to resist, physical blockades at test drilling operations became a key component of the campaign. These grew in size each time, coming to a climax at a site named Bentley in early 2014 - only 15 minutes' drive from the town of Lismore. This blockade was sustained for five months and grew to hundreds permanently camping there. When a police response was anticipated, thousands of people arrived at the site before dawn to support the blockade. As dawn broke they were told the police response was cancelled and the company's licence was being suspended. The Hon Anthony Roberts, NSW Minister for Resources and Energy, made the announcement public on $15^{\text {th }}$ May 2014 (Roberts 2014). This was followed by a scheme by the NSW state government to buy back all CSG licences in the Northern Rivers region (Shoebridge 2016). 


\section{Findings: information provision and policy rationale}

The provision of good-quality and timely information is a central requisite for democracy (Facchini 2019; Judge 2014; Urbanati 2008). Access to information underpins the principle of transparency, and also informs assessments of performance, as stakeholders require information in order to be able to scrutinise the costs and benefits of options and determine whether they meet their objectives. Information also contributes to accountability: when people are better informed they can ensure their electoral preferences are consistent with their values. 'Capability' influences an organisation's ability to provide information and alternative policy rationales, which is dependent on the availability of skilled personnel and other resources. In both case studies analysed here, local governments contributed to the quality and range of information available to citizens. They provided alternative sources of information and alternative arguments to those promoted by state governments and project proponents. Interview participants mentioned the challenge and the importance of access to expertise in opposing a statesupported project (community 9, local government 3 and 8). For CSG, there was public concern that the nature of the proposed operations, including use of the phrase 'natural gas' and other terminology, was inaccurate and under-played potential risks (Deem 2016). In the case of the East West Link, the business case for the project was not released, which limited the public's ability to respond to the state government's and proponent's rationale for the project. The local governments' campaign had a strong focus on gaining access to the business case, and this was the central rationale for their legal action against the project.

Local governments in both case studies contributed to alternative sources of information about the projects using in-house expertise, by facilitating forums which aired independent research, and by sharing information about proposed development activities. In interviews, members of the community remembered Yarra City Council bringing their attention to the project:

Councillors were instrumental in getting information about what was happening; they had a legitimate position, to get information ... They first brought it to our attention early on... they're a canary in the coal mine (community 2).

Councils contributed their technical knowledge, identifying issues with the project, and generated a business case for an alternative project called Doncaster Rail. They networked with experts, who spoke at community meetings sharing evidence of the impacts of similar projects (local government 2 and 5). They also promoted alternative policy messages within the community, including through signage and flyers (community 2 and 5). Both Yarra City Council and Lismore City Council shared information about the location of planned test drilling to inform community protest activities (community 4, 8 and 9). Lismore City Council also initiated a project with other local governments in its region to commission a baseline assessment of groundwater against which impacts of unconventional gas activities could be monitored (local government 7). These actions demonstrate how local government knowledge and resources increased and diversified the information available to citizens. Councils increased transparency by sharing information they had access to, as a level of government, that the 
community would not otherwise have had, and thus contributed to creating more informed citizens. In turn this increased electoral accountability for the respective state governments, as voters were informed and willing to change their vote to align with their policy preferences.

Local governments also contributed to alternative policy messaging. Yarra, already an advocate for public transport, generated a positive message of 'Trains not toll roads', and produced signage, flyers and other material and activities to promote this message (community 5, local government 5). In Northern NSW, it was the community which generated the alternative narrative, and community members who were connected with local governments kept them in step on the campaign. Interview participants described how early messaging against fracking evolved into more strategic messaging of a 'gas field-free Northern Rivers' (local government 7, community 8). Meanwhile, local governments pressured state governments to improve transparency, and highlighted the governance failings of not doing so. The capability of local governments also influenced their ability to enhance governance for these projects by contributing their resources and skills to the issues.

\section{Findings: Increasing participation and deliberation}

'Inclusivity' requires that all stakeholders are able to participate in and affect decision-making, while 'fairness' is about who should have the power to influence a decision, and who bears the costs and benefits (Pomeranz and Stedman 2020). Other literature supports the inclusion of the voices of those most impacted by a decision (Benham 2016; Goetz and Gaventa 2001; Shapiro 2012). 'Legitimacy' can be described as an extension of these two principles. If stakeholders are not included in decision-making and if decisions are not 'fair' in terms of who bears the costs and reaps the benefits, the legitimacy of the decision is called into question. 'Direction' also relates to these concepts as deliberation can create an environment where more people are able to contribute to the vision of the future of a place and to influence whether that aligns with their well-being and values.

Community engagement seeks to increase inclusion and fairness. It is also part of the core business of local governments, required by legislation in every Australian state (Christensen and McQuestin 2019). The case studies analysed here include two local governments (Yarra City Council in Melbourne, and Lismore City Council in Northern NSW) which have been particularly progressive in their commitment to community participation and inclusion. Both have a culture and embedded practices of community engagement, established over decades to protect community identity and in response to previous threats to the local community. This history influenced the extent to which these local governments advocated for their communities in relation to the East West Link and Coal Seam Gas projects (de Vries 2020).

In response to these projects, Yarra and Lismore local governments undertook deliberative visionsetting and community planning, which took place within an existing framework of open council meetings where community members can share information and ask questions (local government 1 , 
community 9). Such meetings provide forums for people to learn about and discuss planning issues in their area. Lismore Council's responsiveness to the community's values was evident early on, even prior to their knowledge of the extent of opposition to CSG - as councillors chose to remain independent from industry funding and influence (local government 8). Similarly, in Melbourne, a number of interview participants spoke about how Yarra City Council was in touch with the views of the community early on, with one commenting, "One thing about Yarra is that they really listen to the community. I've worked at a number of local governments and Yarra is probably one of the strongest in that sense" (local government 5). These deliberative vision-setting opportunities and more informal engagement with councils also contributed to implementing the principle of 'direction', as they enabled inclusive discussions about the future and what types of projects were compatible with the community's vision.

Members of the local community agreed they felt more heard by local government than other levels of government. As one respondent said: "The way I put it is local council is closest to local residents; they hear better than any other level of government because they're constantly there" (community 3).

In both case studies there were early council meetings where the community and local government shared information and joined forces on these campaigns. A councillor in Melbourne spoke about how Yarra's meeting practices enabled this:

Our council meetings are unusual in that anyone can come and speak on anything... any member of the public can turn up, they don't have to give notice, they can decide on the spot that they want to make a submission on something... most councils don't [do this]...There's a lot of community engagement, which engenders a lot of debate and discussion and people feel involved (local government 1).

Further, in Northern NSW, a member of the community remembered the first time he spoke to his local government, Lismore City Council, about CSG:

We had a [Greens] councillor... He put up a motion, [and] the public get a chance to speak to motions... I spoke to the council and left a folder of information for each of them and the motion was passed that we'd have a moratorium at that point. That was the first one, then it got strengthened to a ban at another council meeting... It woke up a few of the councillors (community 9).

A Lismore councillor remembers another councillor who opposed CSG early on: "We would have come to it eventually I'm certain, and it wouldn't have had a different result, but it was [an independent councillor] who brought it to us early, and passionately" (local government 8). It was evident from interviews that open and inclusive council meeting practices were essential for enabling responsive local governments.

Local governments also made significant contributions to campaigns through resourcing and networking with the community. This active role in initiating and resourcing campaign activities was most prominent in the East West Link case study. Yarra City Council in particular set in motion a 
campaign which supported and resourced community ownership of the messages (local government 5, community 5):

We led the campaign to start with, we kicked off the campaign against it, we resourced that, we provided materials, we provided training, leadership and direction - and once community groups formed around this action we supported them to continue it (local government 1).

Yarra City organised a committee early on to generate activity against the East West Link and build support for the alternative of Doncaster Rail (local government 5, community 5) (City of Yarra 2012). This provided a forum for groups to share information and coordinate their activities:

For a lot of people who might have been on the fence about the East West Link, the fact that their council is saying no, this is not a good project, articulating the reasons why and providing that leadership in the community as to why it's not a good project, helps get them over (state government 2).

In Northern NSW, early deliberative activities were initiated by the community. They generated opportunities to talk about CSG, ranging from formal meetings to conversations between friends and neighbours. Citizens initiated a self-survey approach generating 'Gasfield Free Road Declarations', where volunteers went door-to-door along each road, collecting signatures from each resident. Seen as more than a petition, these documents collated the voices of residents to declare the road as 'Gasfield Free'. Lismore City Council then promoted their messages and provided additional forums:

Local government contributed to the movement, because the movement approached local government... but then they became the drivers, their presence was very helpful. Local governments filing motions against it helped give legitimacy to people like me who were just community members... Local governments helped legitimise what was going on and provided yet another forum (community 9).

The Lismore mayor received 'CSG-free-road' declarations from the community, displayed them in her office and advocated for them to state government MPs. Local governments amplified the voices of their communities and advocated for their right to influence decisions that would impact them.

In both case studies there is also evidence of local governments spreading the campaign to other groups, including other local governments in the region:

The 'Trains not toll roads' campaign contacted every local council in Victoria, so we wrote to them a number of times, we got five or six councils that passed resolutions supporting [the campaign] (local government 5).

Creating a regional network strengthened the legitimacy of the Coal Seam Gas campaign and buffered it against threats from the state government (community 5). All Northern Rivers local governments became opposed to CSG; however this was not the case in 2010, or in 2013 as the campaign was escalating (local government 8). Both Lismore community members and councillors helped to spread the campaign to other municipalities (community 9). This enabled a regional response to projects that cross local government areas, contributing to the legitimacy of campaigns - a strategy which is found 
effective by other research into local government advocacy that focuses on regional coalitions of local governments (Granberg et al. 2019; Henderson 2017).

As increased participation and deliberation on these major projects resulted in mounting opposition, the legitimacy of state government support for the projects was called into question. Local governments' own legitimacy, as elected representatives, made a significant contribution to this shift, as the following examples illustrate:

The fact that they [local governments] were there and presenting arguments gave a lot more weight to it: that encourages people, the fact that you've got your council on side means that you've got some authority (state government 1, East West Link).

All along the support of local government was really, really important... In some ways it validates what you're doing: there's other groups of people there, they have access to resources that community groups don't have, they supported and facilitated a lot (community 3, East West Link).

The sum of all the parts made the whole. I think that we certainly contributed, Lismore contributed, the mayors who turned up contributed... We had a lot of conversations with politicians, we made sure we were front and centre. When you've got your local leaders supporting you, I think it makes a difference in terms of being taken seriously in Sydney and Canberra (local government 9, Coal Seam Gas).

In the case of the East West Link, legal action against the project was instrumental in casting doubt over the legitimacy of the state government's position, with the community and local governments lodging separate legal actions. The local government action helped to trigger policy change, by encouraging the state Labor party opposition to change its position and undertake to not honour signed contracts for the project. Labor was subsequently elected in late 2014 and proceeded to cancel the project. A local government councillor spoke about Moreland's motivation for lodging legal action:

The way big decisions are made without releasing the information, or cost-benefit analysis for public debate; the fact that you had a government that hadn't floated its intentions with the public prior to an election... we thought there was not only an impact on us but there was also an issue of good governance (local government 3 ).

In Northern Rivers, a Lismore councillor spoke about the way she advocated for the community's Road Declarations to state MPs. Subsequently, Lismore Council ran a poll at its election, in which $87 \%$ of respondents declared they were against CSG extraction. A number of participants spoke about the importance of the poll for legitimising the community's concerns (local government 7 and 8 , community 9).

I've got to say that if not for holding that poll, or plebiscite, or whatever you want to call it, I don't think that the size of the opposition ever would have been adequately acknowledged (community 8).

There is evidence that when the NSW government considered its response to the heightened situation at the Bentley blockade (see above), it viewed the support of local governments in the region as testifying to the strength of the communities' position against the industry (Shoebridge 2014). These 
discussions contributed to the NSW government's decision to call off a planned police intervention and implement a buyback programme for all CSG licences in the region.

Thus local government activities to increase participation and deliberation made significant contributions to good governance for decision-making about these major projects, by increasing inclusivity, fairness and legitimacy. Local governments' legitimacy helped to overcome questions about the representativeness of the community's position. For the East West Link, the local governments' claims to represent their communities were not questioned, and when in Lismore they were, the council had effective tools to establish the legitimacy of its stance by demonstrating the breadth of grassroots support via polling.

\section{Barriers to local government advocacy for major projects}

In both cases analysed, there was evidence of a lack of desire by state governments for genuine community engagement, as well as evidence of closed state government decision-making processes for the projects (Deem 2016; Legacy 2016). Local governments came up against a number of challenges in advocating against these state-supported projects. In both cases councils faced threats of sackings and defunding, both directly from state governments and through the media:

There were a lot of threats: we didn't get funding [on other projects], Yarra was on the outside... we had to be very careful because the state government said we weren't allowed to advocate outside your local government area, even though the Act says you can advocate for your communities (local government 5).

Reluctance to fund advocacy-style activities was more evident in NSW, with participants citing the weaker 'mandate' for local government in their state:

Constitutionally, the difficulty with local government in Australia is that it's not a layer of government, strictly, legally... your powers are given to you by the state and the state can take them away (local government 8).

Steven Henderson (2018), one of the key contemporary researchers on local government advocacy in Australia, uses the term 'shadow of hierarchy' to describe the way state governments influence the activities of local government. The case studies reviewed here support his theory, providing evidence of ways in which this 'shadow of hierarchy' operates. Notably, the political-party affiliations of local councillors initially limited their responsiveness to local concerns; and correspondingly the most responsive councillors were independent or minor party councillors (local government 1 and 9, community 7):

Council was largely to one side, Council can't take a leadership role in that sense, because we would be seen to be, anti-national party, anti-coalition... Council could not use its funds to go out and advocate on that issue (local government 7).

Interviews also indicated constraints on funding, and perceptions about the acceptability of using funds to oppose state government positions, as key limitations. Consistent with the literature, state government control over local governments was found to be a key factor constraining the ability of local 
governments to represent the interests of their communities (Grant and Dollery 2012). The ability for local governments to act in partnership with other interest groups and to influence the broader political narrative about the issues in play helped to overcome this constraint, as state governments had to respond to emerging public demands regardless of an individual council's activities.

\section{Discussion}

The comparison between these two cases finds that legislative support for local government advocacy is likely to improve its contribution to good governance. There was a notable difference between the two over the extent to which the local governments felt able to spend time and resources on advocacy, which reflected the legislation in each jurisdiction. The Local Government Act 1993 (NSW) encourages community engagement, but it is silent on the issue of local government advocacy. In the Northern NSW case study, the most proactive local governments had sound community engagement practices, consistent with, or in fact surpassing, those required by the Act. However, interviewees in this case study indicated that they felt it was not within their remit to spend funds on advocacy or to actively generate campaigns. In contrast, the Local Government Act 1989 (Victoria) explicitly mentioned advocacy as a legitimate activity of local governments, and in the Melbourne case studied, local governments were more confident of their right to advocate for their communities. Although they were pressurised not to do so by the media and by the Victorian state government, they did allocate funding to advocacy and they did actively generate campaigning activities.

These findings are consistent with the different mandates for local government in effect at the time of the case studies in each state. While in NSW advocacy is not explicitly banned, norming and organisational culture decreased the confidence of local governments to act in this space. It is also very likely a chicken and egg scenario where a strong commitment by Melbourne's inner-city councils to advocacy has ensured that this activity has, until recently, been specifically protected in Victorian local government legislation. However, since the case studies were completed there has been a substantial review of and update to Victorian local government legislation. The Victorian Local Government Act 2020 increases the requirement on local governments to undertake deliberative engagement with their communities. However 'advocacy', as a key component of deliberative systems, is notable by its absence in the updated Act - even though many matters of great importance to local communities are decided at higher levels of government. Instead, the new Act focuses on the inputs of deliberative activities rather than the outputs, even though research suggests the decision-making context is more influential than the engagement process for determining the success of community participation (Savini and Grant 2020). This study supports that supposition by highlighting the important role advocacy by local governments can play in influencing the policy making environment, in partnership with deliberative and traditional community engagement practices. State governments are encouraging local governments to enhance deliberative engagement, but perhaps not to the extent that it can impact upon 
their own decision-making autonomy. Other legislative opportunities relate to Acts that regulate major project approvals, of which there are a number in each jurisdiction depending on the type of activity being pursued. There is room to reconfigure these assessment processes for major projects, to ensure that there is early and genuine engagement with key stakeholders and local governments:

Find out what's happening on the ground... [local governments are] their biggest resource, and I don't think they're taking advantage of it. If they'd come to us six years ago and asked 'What do you think about CSG at Bentley?', I would have said 'Wow, what an extraordinarily poor idea', but nobody asked the question, and that gobsmacks me. How can you make decisions about our region, or an area, if you haven't engaged with the local councils? (local government 9).

The present study also makes a contribution to Schafer's call for research to better understand how representative and deliberative democratic systems interact (Schafer 2017). It finds that deliberative approaches can improve the quality of representative democracy. This was observed through the way that deliberative approaches created more informed voters, who were willing to change their vote despite state government policy positions, which therefore increased the accountability function of elections.

\section{Conclusion}

This research has investigated how local government advocacy can contribute to good governance through enhancing information, participation and deliberation about major projects. Local governments can increase the quality and breadth of information available to citizens. This increases transparency, performance, accountability and capability (four of the principles synthesised by Pomeranz and Stedman 2020) in the decision-making system, by enabling citizens to take part in important decisions which impact them, to scrutinise the costs and benefits of projects, and to consider the merits of alternative courses of action. Local governments can also increase levels of participation in and deliberation about the merits of major projects. This improves inclusivity, fairness, legitimacy and direction (the other four principles synthesised by Pomeranz and Stedman), by increasing the number of people engaged in discussions about the project, representing their views, and challenging the legitimacy of state government positions when they do not properly take into account the views of local residents.

The research has also scoped the unique contribution that can be made by local governments: firstly, through their access to information that other groups may not have; secondly, through their skills, resources and capacity which enable them to create forums for information dissemination and deliberation; and thirdly, through their legitimacy, which can provide an impetus for local residents to learn about and engage on issues that they might not otherwise. This work by local governments also provides a signal to decision-makers, key stakeholders and citizens outside of the community, who may otherwise struggle to get an accurate picture of the representativeness of a campaign or political movement. 
While the research also identified a number of barriers to local government advocacy, including political party influence and funding and media pressures, it found that although local governments may operate within a 'shadow of hierarchy', in Australia they can nevertheless advocate in the face of these challenges. Strengthening the legitimacy of proactive local government advocacy through supportive legislation can further enhance good governance in decision-making about major projects.

\section{Acknowledgements}

I would like to acknowledge the Bundjalung and Wurundjeri people of the Lismore area and Fitzroy area respectively, as the Traditional Owners and ongoing custodians of the land where these case studies took place. I would like to pay my respects to their elders past, present and emerging. I would also like to acknowledge the support of my supervisors and the generosity of the interview participants who shared their time and knowledge with me to make this research possible.

\section{Declaration of conflicting interest}

The author declared no potential conflicts of interest with respect to the research, authorship, and/or publication of this article.

\section{Funding}

The author received research funding through a university-based scholarship from the University of Queensland in support of the research for this article.

\section{References}

Ainsworth, M. (2014) Two councils use more than \$100k of ratepayers cash to fund Link battle. The Herald Sun, 14 September 2014. Available at: www.heraldsun.com.au/news/victoria/two-councils-use-morethan-100k-of-ratepayers-cash-to-fund-link-battle/news-story/3191a918f38c64d29e6fea4075fe9590 [Accessed 1 July 2018].

Amosa, D.U. (2010) Local government and good governance: The case of Samoa. Commonwealth Journal of Local Governance, (7), 7-21. https://doi.org/10.5130/cjlg.v0i7.1891

Benham, C. (2016) Change, opportunity and grief: Understanding the complex social-ecological impacts of liquefied natural gas development in the Australian coastal zone. Energy Research \& Social Science, 14, 61-70. https://doi.org/10.1016/j.erss.2016.01.006

Bennett, A. (2004) Case study methods: Design use and comparative advantages. In: Detlef, F. and Yael, W. (eds) Models, numbers and cases: Methods for studying international relations (pp. 406-408). Ann Arbor: University of Michigan Press.

Christensen, H. and McQuestin, D. (2019) Community engagement in Australian local governments: A closer look and strategic implications. Local Government Studies, 45 (4), 453-480. https://doi.org/10.1080/03003930.2018.1541794

City of Yarra. (2012) Ordinary meeting of council minutes 7 February 2012. Melbourne: City of Yarra.

Coghill, K., Ng, Y.-F. and Thornton-Smith, P. (2014) Enhancing local government democracy: City of Melbourne. Electoral Regulation Research Network. Melbourne: Victorian Electoral Commission.

Crowley, K. (1998) 'Glocalisation' and ecological modernity: Challenges for local environmental governance in Australia. Local Environment, 3 (1), 91-97. https://doi.org/10.1080/13549839808725549

de Vries, S. (2020) Place identity and major project deliberation: The contribution of local governments in Australia. Australian Geographer, 51 (3), 399-419. https://doi.org/10.1080/00049182.2020.1788269 
Deem, R (2016) Gasfield free NSW Northern Rivers: Non-violent, non-negotiable. Australian eBook Publisher.

Dovers, S. and Hussey, K. (2013) Environment and sustainability: A policy handbook. Sydney, Australia: The Federation Press.

Dryzek, J. (2010) Foundations and frontiers of deliberative governance. Oxford: Oxford University Press. https://doi.org/10.1093/acprof:oso/9780199562947.001.0001

Eddington, S.R. (2008) Investing in transport: East West Link needs assessment. Victorian Government, Melbourne. Available at: ycat.org.au/archived-sites/eddington-investing-in-transport-report-2008/

Ercan, S. and Hendriks, C.M. (2013) The democratic challenges and potential of localism: Insights from deliberative democracy. Policy Studies, 34 (4), 422-440. https://doi.org/10.1080/01442872.2013.822701

Facchini, F. (2019) The democratic crisis and the knowledge problem. Politics \& Policy, 47(6), 1022-1038. https://doi.org/10.1111/polp.12330

Goetz, A.M. and Gaventa, J. (2001) From consultation to influence: Bringing citizen voice and client focus into service delivery. Brighton: Institute of Development Studies.

Graham, J., Amos, B. and Plumptre, T. (2003) Principles of good governance in the 21st century. Ottawa, Ontario: Institute on Governance. Available at: academia.edu/263793/Principles_for_good_governance_in_the_21 ${ }^{\text {st }}$ _century

Granberg, M., Bosomworth, K., Moloney, S., Kristianssen, A. and Fuenfgeld, H. (2019) Can regional-scale governance and planning support transformative adaptation? A study of two places. Sustainability, 11, 117. https://doi.org/10.3390/su11246978

Grant, B. and Dollery, B. (2012) Autonomy versus oversight in local government reform: The implications of 'home rule' for Australian local government. Australian Journal of Political Science, 47 (3), 399-412. https://doi.org/10.1080/10361146.2012.704003

Gutmann, A. and Thompson, D. (2000) Why deliberative democracy is different. Social Philosophy and Policy, 17(1), 161-80. https://doi.org/10.1017/S0265052500002570

Henderson, S. (2017) Competitive sub-metropolitan regionalism: Local government collaboration and advocacy in northern Melbourne, Australia. Urban Studies, 55 (13), 2863-2885. https://doi.org/10.1177/0042098017726737

Henderson, S. (2018) Advocating within and outside the shadow of hierarchy: Local government responses to Melbourne's outer suburban deficits. Local Government Studies, 44 (5), 649-669. https://doi.org/10.1080/03003930.2018.1481397

Hendriks, C.M., Bolitho, A. and Foulkes, C. (2013) Localism and the paradox of devolution: Delegated citizen committees in Victoria, Australia. Policy Studies, 34 (5-6), 575-591. https://doi.org/10.1080/01442872.2013.862450

Heywood, P. (2011) Community planning: Integrating social and physical environments. Chichester: WileyBlackwell.

Judge, D. (2014) Democratic incongruities: Representative democracy in Britain. London: Palgrave Macmillan. https://doi.org/10.1057/9781137317292

Katz, B.J. and Nowak, J. (2017) The new localism: How cities can thrive in the age of populism. New York: Brookings Institution Press.

KPMG (2015) Improving local governments role in the assessment process for major projects in Queensland. Brisbane: Local Government Association of Queensland (LGAQ).

Ladner, A., Keuffer, N., Baldersheim, H., Hlepas, N., Swianiewicz, P., Steyvers, K. and Navarro, C. (2019) Patterns of local autonomy in Europe. Cham, Switzerland: Palgrave Macmillan. https://doi.org/10.1007/978-3-319-95642-8

Lawton, A. and Macaulay, M. (2014) Localism in practice: Investigating citizen participation and good governance in local government standards of conduct. Public Administration Review, 74 (1), 75-83. https://doi.org/10.1111/puar.12161

Legacy, C. (2016) Transforming transport planning in the postpolitical era. Urban Studies, 53 (14), 3108-3124. https://doi.org/10.1177/0042098015602649 
Lismore City Council. (2018) Council decisions relating to coal seam gas mining. Lismore City Council, Available at: www.lismore.nsw.gov.au/cp_themes/default/page.asp?p=DOC-QDF-04-78-50 [Accessed 4 March 2018].

Lockwood, M., Davidson, J., Curtis, A., Stratford, E.and Griffith, R. (2010) Governance principles for natural resource management. Society and Natural Resources, 23 (10), 986-1001. https://doi.org/10.1080/08941920802178214

Lucas, C. and Gordon, J. (2015) Victorian government settles East West Link claim for \$339m. The Age. April 15 2015. Available at: https://www.theage.com.au/national/victoria/victorian-government-settles-eastwest-link-claim-for-339m-20150415-1ml9bz.html

Maloney, D.A.W. (2015) Unconventional oil and gas in Australia: A case of regulatory lag. Journal of Energy \& Natural Resources Law, 33(4), 349-404. https://doi.org/10.1080/02646811.2015.1089112

Mansbridge, J., Bohman, J., Chambers, S., Christiano, T., Fung, A., Parkinson, J., Thompson, D. and Warren, M.E. (2012) A systemic approach to deliberative democracy. In: Parkinson, J. and Mansbridge, J. (eds) Deliberative systems: Deliberative democracy at the large scale, (pp. 1-26). Cambridge: Cambridge University Press. https://doi.org/10.1017/CBO9781139178914.002

McGowan, F. (2012) Regulating innovation: European responses to shale gas development. Environmental Politics, 23 (1), 41-58. https://doi.org/10.1080/09644016.2012.740939

Muyomba-Tamale, L. and Cunningham, K. (2019) Holding governments accountable for service delivery: The local government councils scorecard initiative in Uganda. Commonwealth Journal of Local Governance, (20), 187-205. https://doi.org/10.5130/cjlg.v0i20.6497

Northern Star (2012) Lismore residents CSG vote. 16 June 2012. Available at: www.northernstar.com.au/news/lismore-residents-csg-vote-/1420141/

Pomeranz, E.F. and Stedman, R.C. (2020) Measuring good governance: Piloting an instrument for evaluating good governance principles. Journal of Environmental Policy \& Planning, 22 (3), 428-40. https://doi.org/10.1080/1523908X.2020.1753181

Pratchett, L. (2004) Local autonomy, local democracy and the 'new localism'. Political Studies, 52 (2), 358 375. https://doi.org/10.1111/j.1467-9248.2004.00484.X

Roberts, A. (2014) Metgasco drilling approval suspended. Available at: https://resourcesandgeoscience.nsw.gov.au/_data/assets/pdf_file/0011/531875/140515-MetgascoDrilling-Approval-Suspended.pdf

Savini, E. and Grant, B. (2020) Legislating deliberative engagement: Is local government in Victoria willing and able? Australian Journal of Public Administration, 79 (4), 514-530. https://doi.org/10.1111/14678500.12420

Schafer, A. (2017) Deliberation in representative institutions: An analytical framework for a systemic approach. Australian Journal of Political Science, 52 (3), 419-435. https://doi.org/10.1080/10361146.2017.1330397

Schoburgh, E. and Ryan, R. (2017) Handbook of research on sub-national governance and development. Pennsylvania, USA: IGI Global. https://doi.org/10.4018/978-1-5225-1645-3

Shapiro, I. (2012) On non-domination. University of Toronto Law Journal, 62 (3), 293-335. https://doi.org/10.3138/utlj.62.3.293

Shoebridge, B. (2016) The Bentley effect. Documentary. Half Smile Productions Pty Ltd. Trailer available at: https://www.thebentleyeffect.com/

Shoebridge, D. (2014) Crushing police force planned to end peaceful CSG blockade. David Shoebridge MLC, Available at: http://davidshoebridge.org.au/2014/07/23/crushing-police-force-planned-to-end-peacefulcsg-bloackade/ [Accessed May 2018].

Smith, W. (2016) The boundaires of a deliberative system: The case of disruptive protes. Critical Policy Studies, 10 (2), 152-170. https://doi.org/10.1080/19460171.2016.1165128

Stoker, G. (2006) Why politics matters: Making democracy work. New York: Palgrave Macmillan.

Thwaites, R.N., Carter, J.L. and Norman, P.L. (2004) Community based resource planning: Studies from Zimbabwe and Northern Australia. Australian Centre for International Agricultural Research. Available 
at: https://aciar.gov.au/publication/books-and-manuals/community-based-resource-planning-studieszimbabwe-and-northern-australia

UNDP. (2006) UNDP and governance: Experiences and lessons learned. New York, NY: United Nations Development Programme. Available at: https://www.eldis.org/document/A27710

Urbanati, N. (2008) Representative democracy: Principles and genealogy. Chicago: University of Chicago Press.

Van Assche, D. and Dierick, G. (2007) The decentralisation of city government and the restoration of political trust. Local Government Studies, 33 (1), 25-47. https://doi.org/10.1080/03003930601081069

Victorian Government. (1989) Local Government Act 1989 (Vic). Available at: http://www.legislation.vic.gov.au/domino/Web_Notes/LDMS/LTObject_Store/ltobjst9.nsf/DDE300B84 6EED9C7CA257616000A3571/BDFF95C10DE3BD01CA257F0E0082D5F2/\$FILE/8911aa135\%20authorised.PDF

VLGA, MAV, LGV and LGPro. (2012) Good governance guide: Helping local governments govern better. Melbourne. Available at: www.vlga.org.au/sites/default/files/VLGA.2012-1008\%20Good\%20Governance\%20Guide.pdf

Williams, L. (2020) Energy democracy, dissent and discourse in the party politics of shale gas in the United Kingdom. Environmental Politics, 29 (7), 1239-1263. https://doi.org/10.1080/09644016.2020.1740555 